\title{
SISTEM PENDUKUNG KEPUTUSAN PENERIMA BANTUAN SISWA MISKIN (BSM) DI SDN 005 BUKIT TIMAH DENGAN MENGGUNAKAN METODE AHP
}

\author{
Nur Rubiati ${ }^{1}$, Rahmad Kurniawan ${ }^{2}$, Listri Septiana ${ }^{3}$ \\ ${ }^{1,2,3}$ Sekolah Tinggi Manajemen Informatika \& Komputer ( STMIK ) Dumai \\ Jln. Utama Karya Bukit Batrem Dumai-Riau Kode Pos 28811 \\ email : nurrubiati0412@gmail.com ${ }^{1}, \underline{\text { rahmad0412@gmail.com }}^{2}$, \\ listriseptiana@gmail.com ${ }^{3}$
}

\begin{abstract}
ABSTRAK
SDN 005 Bukit Timah kota Dumai masih memilih secara manual rekomendasi calon penerima bantuan siswa miskin (BSM). Oleh karena itu diperlukan sebuah aplikasi yang dapat menentukan siapa siswa yang berhak mendapatkan BSM. Aplikasi yang dibuat menggunakan bahasa pemograman PHP dan database MySQL. Pada aplikasi tersebut menggunakan kriteria yaiu : Alat Transportasi, Penghasilan orang tua, kelas, Kepemilikan orang tua, Tanggungan orang tua, Jarak rumah, Pertimbangan lain (pertimbangan sekolah/usulan sekolah). Dengan adanya aplikasi ini diharapkan siswa yang mendapatkan bantuan siswa miskin adalah layak dan tepat sasaran.
\end{abstract}

Kata kunci : PHP, Siswa, AHP

\section{ABSTRACT}

SDN 005 Bukit Timah, Dumai city, still manually chooses the recommendation of prospective poor student assistance recipients (BSM). Therefore we need an application that can determine who students are entitled to get BSM. Applications created using the PHP programming language and MySQL database. The application uses the following criteria: Transportation Equipment, Parents' Income, Classes, Parental Ownership, Dependents of Parents, Distance of Home, Other Considerations (school considerations / school proposals). With this application it is expected that students who get help from poor students are worthy and right on target.

Keywords : PHP, Students, AHP

\section{PENDAHULUAN}

Dinas Pendidkan dan Kebudayaan Kota Dumai mempunyai program memberikan Bantuan Siswa Miskin (BSM). Salah satu sekolah yang mendapat bantuan tyersebut adalah SD Negeri 005 Bukit Timah. SD Negeri 005 Bukit Timah dalam memilih dan meyeleksi siswa untuk BSM memerlukan waktu yang lama dikarenakan masih menggunakan proses mencatat dan menerka - nerka, sehingga sering terjadi kesalahan. Untuk itu diperlukan sebuah sistem yang dapat memberikan keputusan siapa siswa yang berhak dan layak mendapatkan BSM. Aplikasi ini dbuat menggunakan bahasa pemograman PHP dan Database MySQL sebagai tempat penyimnan data dan agar data tidak terjadi redudansi.

\section{a. Sistem}

Sistem adalah suatu kumpulan atau himpunan dari unsur, komponen, atau variabel yang terorganisir, berinteraksi, saling tergantung satu sama lain, dan terpadu. (Sutabri, 2012)

Sistem adalah sekumpulan elemen yang saling terkait atau terpadu yang dimaksudkan untuk mencapai suatu tujuan. (Kadir, 2014)

\section{b. Sistem Pendukung Keputusan (SPK)}

Konsep Sistem Pendukung Keputusan atau Decision Support System pertama kali diungkapkan pada awal tahun 1970-an oleh Michael S. Scott Morton dengan istilah Management Decision System. Definisi dari Sistem Pendukung Keputusan adalah sekumpulan prosedur berbasis model untuk data pemrosesan dan penilaian guna membantu para maneger 
INFORMA TIKA

Jurnal Informatika, Manajemen dan Komputer, Vol.11 No.2, Desember 2019

eISSN : 2580-3042

pISSN : 1979-0694

mengambil keputusan" Dia menyatakan bahwa untuk sukses, sistem tersebut harus sederhana, cepat, mudah di kontrol, adaptif,lengkap dengan isu-isu dan mudah berkomunikasi”. (Turban, 2005)

Menurut Dwi Citra Hartini (2013) dalam jurnal(Hardianti, Hidayatullah, Pratiwi, \& Hadiansa, 2018) Sistem Pendukung Keputusan merupakan sistem informasi interaktif yang menyediakan informasi, pemodelan, dan pemanipulasian data. Sistem ini digunakan untuk membantu pengambilan keputusan dalam situasi yang semiterstruktur dan situasi yang tidak terstruktur, dimana tidak seorang pun tahu secara pasti bagaimana keputusan seharusnya dibuat.

\section{c. Sistem Rekomendasi}

Menurut Melville (2010) Sistem rekomendasi adalah sebuah sistem informasi komputer yang membantu membuat keputusan untuk aktivitas bisnis dan organisasi. Sistem Rekomendasi dibuat dengan tujuan untuk memberikan rekomendasi kepada pengguna mengenai produk yang mungkin menarik untuk pengguna. (Pratama \& Hansun, 2017)

\section{d. Bantuan Siswa Miskin}

Menurut Kementrian Agama Republik Indonesia. (2012) BSM adalah singkatan dari Bantuan Beasiswa Siswa Miskin yang dikeluarkan oleh pemerintah menggunakan dana dari APBN. Dengan program Bantuan Beasiswa Siswa Miskin ini, diharapkan dapat membantu sebagian siswa yang berasal dari keluarga kurang mampu/miskin di lingkungan sekolah dalam membiayai sebagian kebutuhan pendidikannya, sehingga dapat menyelesaikan pendidikannya, bahkan dapat melanjutkan pendidikan ke jenjang berikutnya. (Arief, Thamrin, \& Budiawan, 2015)

\section{e. Metode Analytical Hiierarchy Process (AHP)}

Proses pengambilan keputusan adalah memilih suatu alternatif. Peralatan utama AHP adalah sebuah hierarki fungsional dengan input utamanya persepsi manusia. Keberadaan hierarki memungkinkan dipecahnya masalah kompleks atau tidak terstruktur dalam sub-sub masalah, lalu menyusunkan menjadi suatu bentuk hierarki.(Kusrini, 2007)

Analytical Hierarchy Process (AHP) adalah suatu hierarki fungsional yang input utamanya adalah persepsi manusia. (Bain Khusnul Khotimah, Firli Irhamni, Moh. Zein Saedi, 2015)

Implementasi AHP telah banyak digunakan dalam menyelesaikan beberapa jenis masalah spasial seperti perencanaan penggunaan lahan,

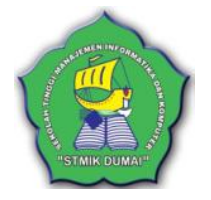

pemilihan lokasi, pemilihan alternatif keputusan, kepuasan pelanggan.(Ayu Riana Devi Aprilia, 2018)

Menurut Simanjorang (2017) di dalam jurnal (Rahmiati \& Yenni, 2019) ,Metode AHP merupakan suatu model pengambilan keputusan yang komprehensif dengan memperhitungkan halhal yang bersifat kualitatif dan kuantitatif.Hal ini disebabkan konsepnya sederhana dan mudah dipahami, komputasinya efisien dan memiliki kemampuan untuk mengukur kinerja relatif dari alternatif-alternatif keputusan.AHP adalah suatuteori umum tentang pengukuran yang digunakan untuk menemukan skala rasio, baik dari perbandingan berpasangan yang diskrit maupun kontinyu.

\section{METODOLOGI PENELITIAN}

Adapun langkah-langkah yang digunakan dalam membuat sistem dengan metode waterfall untuk menggambarkan rangkaian ide yang disusun secara sistematis, logis, jelas dan terstruktur sebagai berikut :

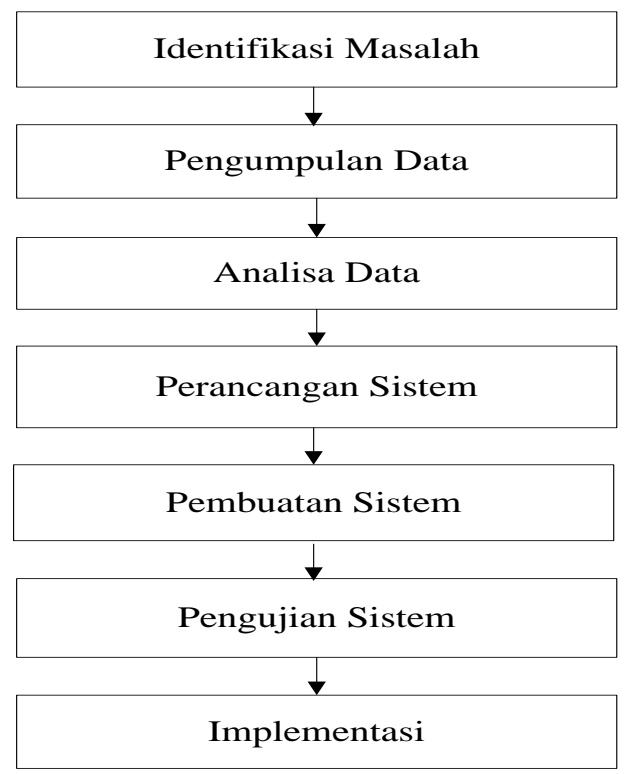

Gambar 1. Kerangka Penelitian

Berikut ini adalah penjelasan kerangka penelitian menggunakan model waterfall:

1. Identifikasi Masalah

Tahap pertama yang dilakukan dalam penelitian adalah mengetahui permasalahan yang sedang dihadapi SD Negeri 005 Bukit Timah dalam memilih siswa penerima BSM, sehingga akan dianalisa untuk ditemukan penyelesaianya.

2. Pengumpulan Data

Tahap selanjutnya adalah pengumpulan data yang berhubungan dengan masalah yang telah di 
IN F O R M A I I A

Jurnal Informatika, Manajemen dan Komputer, Vol.11 No.2, Desember 2019

eISSN : 2580-3042

pISSN : 1979-0694

ketahui. Adapun teknik yang di lakukan dalam pengumpulan data sebagai berikut:

1) Field Research (Penelitian Lapangan)

Penelitian ini dilakukan dengan pengamatan langsung ke tempat penelitian untuk mendapatkan informasi yang diperlukan. Dalam pengumpulan informasi digunakan teknik sebagai berikut :

a. Teknik Wawancara

Teknik wawancara dalam penulisan ini adalah melakukan wawancara langsung ke Kepala sekolah, bagian kesiswaan dan tata uasaha SD Negeri 005

b. Observasi

Teknik ini melakukan pengumpulan data dengan mengambil data siswa dan melakukan pengamatan secara langsung pada SD Negeri 005 Bukit Timah.

2) Library Research (Penelitian Perpustakan)

Penelitian ini dilakukan dengan cara mengumpulkan data dan mempelajarinya, berupa teori-teori yang bersumber dari buku referensi, jurnal yang diambil dari internet yang sudah memiliki ISSN maupun sumber lainnya yang berhubungan dengan permasalahan yang akan diteliti.

3) Laboratory Research (Penelitian Laboratorium)

Penelitian lain yang juga dilakukan adalah penelitian laboratorium yang merupakan sarana dalam menunjang penyelesaian pembuatan program aplikasi dan pengetikannya.

3. Analisa Data

Data-data tentang siswa yang layak menerima BSM yang telah di kumpulkan dari SD Negeri 005 Bukit Timah akan dianalisa. Dari hasil analisa tersebut data akan digunakan untuk membuat perancangan sistem berdasarkan permasalahan tersebut.

4. Perancangan Sistem

Pada tahap ini penulis akan merancang sistem dalam pemilihan siswa penerima BSM dengan menggunakan bahasa pemograman PHP, database MYSQL dan menggunakan metode Analitycal Hierarchy Process (AHP).

5. Pembuatan Sistem

Pada tahap ini akan dibuat sebuah sistem yaitu Sistem Penunjang Keputusan Pemilihan Penerima Bantuan Siswa Miskin (BSM) Menggunakan Metode Analytical Hierarchy Process (AHP). Sesuai dengan tahapan yang telah dirancang dan disesuaikan dengan pengolahan data sebelumnya.

6. Pengujian Sistem

Sistem yang dibuat hasilnya akan dibandingkan dengan hasil perhitungan manual dan hasil akhir atau output system.

7. Implementasi

Pada tahap ini dilakukan pengimplementasian sistem pada objek penelitian yaitu SD Negeri 005 Bukit Timah untuk mendapatkan hasil yang sesuai dengan yang diharapkan.

\section{HASIL DAN PEMBAHASAN}

a. Tahapan - Tahapan Metode AHP

1. Membuat hierarkhi Penerimaan bantuan

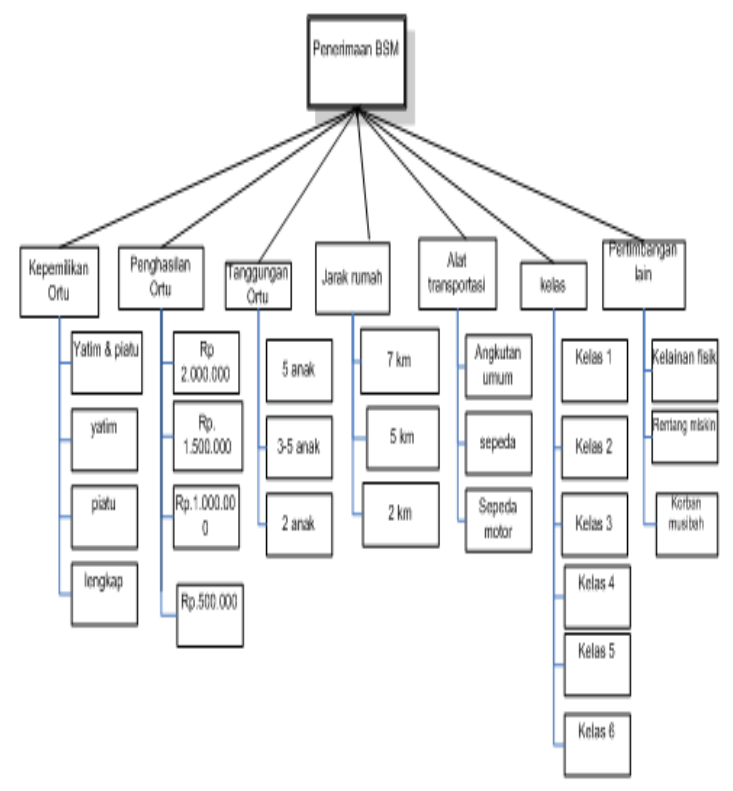

2. Membuat matrik perbandingan berpasangan

Tabel 1. Matriks Perbandingan Berpasangan

\begin{tabular}{|c|c|c|c|c|c|c|c|}
\hline kriteria & $\begin{array}{c}\text { kepemilikan } \\
\text { orangula }\end{array}$ & $\begin{array}{c}\text { penghasilan } \\
\text { orangtua }\end{array}$ & $\begin{array}{c}\text { tanggungan } \\
\text { orangtua }\end{array}$ & $\begin{array}{c}\text { jarak } \\
\text { rumah }\end{array}$ & $\begin{array}{c}\text { Alat } \\
\text { transportasi }\end{array}$ & kelas & $\begin{array}{c}\text { pertimbangan } \\
\text { lain }\end{array}$ \\
\hline $\begin{array}{c}\text { keppemilikan } \\
\text { orangtua }\end{array}$ & 1.00 & 1.00 & 1.00 & 2.00 & 1.00 & 2.00 & 1.00 \\
\hline $\begin{array}{c}\text { penghasilan } \\
\text { orangula }\end{array}$ & 1.00 & 1.00 & 5.00 & 2.00 & 2.00 & 2.00 & 2.00 \\
\hline $\begin{array}{c}\text { tanggungan } \\
\text { orangtua }\end{array}$ & 1.00 & 0.20 & 1.00 & 2.00 & 2.00 & 2.00 & 2.00 \\
\hline jarak rumah & 0.50 & 0.50 & 0.50 & 1.00 & 2.00 & 2.00 & 3.00 \\
\hline $\begin{array}{c}\text { Alat } \\
\text { transportasi }\end{array}$ & 1.00 & 0.50 & 0.50 & 0.50 & 1.00 & 2.00 & 3.00 \\
\hline kelas & 0.50 & 0.50 & 0.50 & 0.50 & 0.50 & 1.00 & 2.00 \\
\hline $\begin{array}{c}\text { pertimbangan } \\
\text { lain }\end{array}$ & 1.00 & 0.50 & 0.50 & 0.33 & 0.33 & 0.50 & 1.00 \\
\hline jumlah & 6.00 & 4.20 & 9.00 & 8.33 & 8.83 & 11.50 & 14.00 \\
\hline
\end{tabular}

Nilai 1.00 pada baris Kepemilikan orang tua dihasilkan dari perbandingan terhadap dirinya sendiri. Sehingga nilai 1.00 akan tampil secara diagonal. Untuk pencarian perhitungan di atas yaitu : Rumus : jumlah $=\mathrm{Cn} / \mathrm{Cn}$ 
IN F ORMA T I K A

Jurnal Informatika, Manajemen dan Komputer, Vol.11 No.2, Desember 2019

eISSN : 2580-3042

pISSN : 1979-0694

Keterangan : $\mathrm{Cn}=$ kriteria

a. pencarian jumlah dari kriteria kepemilikan orangtua

kepemilikan orangtua $=\mathrm{C} 1 / \mathrm{C} 2$

$$
=1 / 1=1.00
$$

kepemilikan orangtua $=\mathrm{C} 1 / \mathrm{C} 3$

$$
=1 / 1=1.00
$$

kepemilikan orangtua $=\mathrm{C} 1 / \mathrm{C} 4$

$$
=1 / 2=0.50
$$

kepemilikan orangtua $=\mathrm{C} 1 / \mathrm{C} 5$

$$
=1 / 1=1.00
$$

kepemilikan orangtua $=\mathrm{C} 1 / \mathrm{C} 6$

$$
=1 / 2=0.50
$$

kepemilikan orangtua $=\mathrm{C} 1 / \mathrm{C} 7$

$$
=1 / 1=1.00
$$

\begin{tabular}{|c|c|c|c|c|c|c|c|c|c|}
\hline Riteria & KO & po & T0 & $\mathbb{R}$ & AT & $\mathrm{KS}$ & $\mathrm{PL}$ & Jumlah & Priorita \\
\hline BO & 0.17 & 0.24 & 0.11 & 0.24 & 0.11 & 0.17 & 0.07 & 1.11 & 0.16 \\
\hline$p 0$ & 0.17 & 024 & 0.56 & 0.24 & 0.23 & 0.17 & 0.14 & 1.74 & 025 \\
\hline To & 0.17 & 0.05 & 0.11 & 0.24 & 023 & 0.17 & 0.14 & 1.11 & 0.16 \\
\hline $\mathbb{R}$ & 0.08 & 0.12 & 0.06 & 0.12 & 023 & 0.17 & 021 & 099 & 0.14 \\
\hline AT & 0.17 & 0.12 & 0.06 & 0.06 & 0.11 & 0.17 & 021 & 090 & 0.13 \\
\hline KS & 0.08 & 0.12 & 0.06 & 0.06 & 0.06 & 0.09 & 0.14 & 0.60 & 0.09 \\
\hline $\mathbb{P L}$ & 0.17 & 0.12 & 0.06 & 0.04 & 0.04 & 0.04 & 0.07 & 053 & 0.08 \\
\hline
\end{tabular}

Begitu langkah seterusnya kriteria saling membandingkan dengan nilai kriteria .

\section{Membuat matrik nilai kriteria}

Tabel 2. Matrik Nilai Kriteria

Untuk pencarian perhitungan di atas yaitu :

Rumus : matrik nilai kriteria $=$ nilai kolom kriteria matrik perbandingan berpasangan / jumlah kolom matrik perbandingan berpasangan Keterangan : $\mathrm{Cn}=$ nilai kriteria kolom

a. pencarian nilai kriteria dari kriteria perbandingan berpasangan kepemilikan orangtua

kepemilikan orangtua $=\mathrm{Cn} /$ jumlah kolom perbandingan berpasangan $=1 / 6.00=0.17$

kepemilikan orangtua $=\mathrm{Cn} /$ jumlah kolom perbandingan berpasangan $=1 / 6.00=0.17$

kepemilikan orangtua $=\mathrm{Cn} /$ jumlah perbandingan berpasangan $=1 / 6.00=0.17$

kepemilikan orangtua $=\mathrm{Cn} /$ jumlah perbandingan berpasangan $=0.50 / 6.00=0.08$ kepemilikan orangtua $=\mathrm{Cn} /$ jumlah perbandingan berpasangan $=1 / 6.00=0.17$

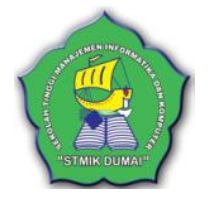

kepemilikan orangtua $=\mathrm{Cn} /$ jumlah perbandingan berpasangan $=0.50 / 6.00=0.08$ kepemilikan orangtua $=\mathrm{Cn} /$ jumlah perbandingan berpasangan $=1 / 6.00=0.17$

Bagitu seterusnya mengikuti langkah yang ada .

4. Matrik penjumlahan setiap baris

Tabel 3. Matrik Penjumlahan Setiap Baris

\begin{tabular}{|c|c|c|c|c|c|c|c|c|}
\hline Kriteria & KO & P0 & TO & IR & AT & KS & PL & Jumlah \\
\hline KO & 0.16 & 0.25 & 0.16 & 0.28 & 0.13 & 0.17 & 0.08 & 1.23 \\
\hline PO & 0.16 & 0.25 & 0.79 & 0.28 & 0.26 & 0.17 & 1.15 & 2.07 \\
\hline TO & 0.16 & 0.05 & 0.16 & 0.28 & 0.26 & 0.17 & 1.15 & 1.23 \\
\hline R & 0.08 & 0.12 & 0.08 & 0.14 & 0.26 & 0.17 & 1.23 & 1.08 \\
\hline AT & 0.16 & 0.12 & 0.08 & 0.07 & 0.13 & 0.17 & 1.23 & 0.96 \\
\hline KS & 0.08 & 0.12 & 0.08 & 0.07 & 0.06 & 0.09 & 1.15 & 0.06 \\
\hline PI & 0.16 & 0.12 & 0.08 & 0.05 & 0.04 & 0.04 & 0.08 & 0.57 \\
\hline. & & & & & & & & \\
\hline
\end{tabular}

Untuk pencarian perhitungan di atas yaitu :

Rumus : nilai matrik penjumlahan setiap baris = nilai baris prioritas matrik nilai kriteria $\mathrm{x}$ nilai baris matrik perbandingan berpasangan

a. pencarian nilai matrik penjumlahan setiap baris dari nilai baris prioritas matrik nilai kriteria $\mathrm{x}$ nilai baris matrik perbandingan berpasangan kepemilikan orangtua

kepemilikan orangtua $=$ nilai baris prioritas matrik nilai kriteria $\mathrm{x}$ nilai baris matrik perbandingan berpasangan $=0.16 \times 1.00=0.16$ kepemilikan orangtua $=$ nilai baris prioritas matrik nilai kriteria $\mathrm{x}$ nilai baris matrik perbandingan berpasangan $=0.16 \times 1.00=0.16$ kepemilikan orangtua $=$ nilai baris prioritas matrik nilai kriteria $\mathrm{x}$ nilai baris matrik perbandingan berpasangan $=0.16 \times 1.00=0.16$

kepemilikan orangtua $=$ nilai baris prioritas matrik nilai kriteria $\mathrm{x}$ nilai baris matrik perbandingan berpasangan $=0.16 \times 0.50=0.08$ kepemilikan orangtua $=$ nilai baris prioritas matrik nilai kriteria $\mathrm{x}$ nilai baris matrik perbandingan berpasangan $=0.16 \times 1.00=$ 0.16 kepemilikan orangtua $=$ nilai baris prioritas matrik nilai kriteria $\mathrm{x}$ nilai baris matrik perbandingan berpasangan $=0.16 \times 0.50=$ 0.08 kepemilikan orangtua $=$ nilai baris prioritas matrik nilai kriteria $\mathrm{x}$ nilai baris matrik perbandingan berpasangan $=0.16 \times 1.00=0.16$ 
IN F ORMA T I K A

Jurnal Informatika, Manajemen dan Komputer, Vol.11 No.2, Desember 2019

eISSN : 2580-3042

pISSN : 1979-0694

5. Membuat Rasio Konsistensi

Tabel 4. Perhitungan Rasio Konsistensi

\begin{tabular}{|c|c|c|c|}
\hline kriteria & jumlah & prioritas & hasil \\
\hline $\begin{array}{c}\text { kepemilikan } \\
\text { orangtua }\end{array}$ & 1.23 & 0.16 & 1.39 \\
\hline penghasilan orangtua & 2.07 & 0.25 & 2.32 \\
\hline tanggungan orangtua & 1.22 & 0.16 & 1.38 \\
\hline jarak rumah & 1.07 & 0.14 & 1.21 \\
\hline Alat transportasi & 0.88 & 0.12 & 1 \\
\hline kelas & 0.66 & 0.09 & 0.75 \\
\hline pertimbangan lain & 0.56 & 0.08 & 0.64 \\
\hline jumlah & & & 8.69 \\
\hline
\end{tabular}

Untuk melakukan perhitungan Konsistensi, kolom jumlah didapat dari nilai prioritas pada Tabel 2. Prioritas didapat dari jumlah tabel 3.

$$
\begin{aligned}
& \Lambda \text { maks }=\underline{1.39+2.32+1.38+1.21+1+0.75+0.64}= \\
& \frac{8.69}{7}=1.24 \\
& \mathrm{CI}=\underline{(\lambda \text { maks-n })}=\underline{1.24-7}=\underline{-5.76}=-0.96 \\
& \mathrm{IR}=1.32 \\
& \text { (n-1) 7-1 } 6 \\
& \mathrm{CR}=\underline{\mathrm{CI}}=\underline{-0.96}=-0.73 \\
& \text { IR } 1.32
\end{aligned}
$$

\begin{tabular}{|c|c|c|c|c|c|c|}
\hline Leperitzan oragntus & pendacizan rasagtou & 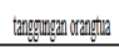 & jaderamah & dat traspontasi & Weleas & perimbanganatien \\
\hline yatim\& potatu & Ro, 2000,000 & 25 anak & $7 \mathrm{~km}$ & anglotan umum & kelas: 1 & kelinanfisik \\
\hline 0.59 & 0.35 & 0.4 & 0.H & 0.6 & 0.31 & 0.32 \\
\hline yatim & Ro. 15000,000 & $3.580 \mathrm{nak}$ & $5 \mathrm{~km}$ & sepeda & kelas2 & retranginition \\
\hline 021 & 0.2 & 0.39 & 0.39 & 0.2 & 0.24 & 0.5 \\
\hline piativ & Ro, 1 1000,000 & 1.2anek & $2 \mathrm{~km}$ & seepeda motior & kelas & Kotannmisioh \\
\hline 0.12 & 0.2 & 0.17 & 0.17 & 0.13 & 0.17 & 0.3 \\
\hline lenglap & Rej50.0OO & & & & kelas 4 & \\
\hline \multirow[t]{5}{*}{0.07} & 0.25 & & & & 0.13 & \\
\hline & & & & & kelas5 & \\
\hline & & & & & 0.11 & \\
\hline & & & & & kelas 6 & \\
\hline & & & & & $0.05 \mid$ & \\
\hline
\end{tabular}

Tabel 5. Matrik hasil

\begin{tabular}{|c|c|c|c|c|c|c|c|}
\hline Nama sisina & keperithenoragta & 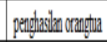 & 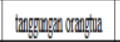 & jadrman & datrespotati & Leths & pertibugyaliz \\
\hline Dimasgagng & patim & Rop 1000.000 & 3.5 ande & $2 \mathrm{~m}$ & sepeda & keters $2 \mathrm{C}$ & retangnising \\
\hline Dimas tumangeoo & lenglep & Re.500000 & 15 andk & $7 \mathrm{~m}$ & sepedal notor & keles $4 \mathrm{~A}$ & rettranginisin \\
\hline Fahri| alams/ant & jotimlopitu & Res0:0000 & 15 anak & $5 \mathrm{~m}$ & aghotan unum & keles $4 \mathrm{~A}$ & rettrongingin \\
\hline ransiscus inmon & lenglep & Ro5000000 & 1.2 andek & $5 \mathrm{~m}$ & sepeded notor & keles $1 \mathrm{~A}$ & rethonginghin \\
\hline Gilaryboin & lenglop & Ro. 500.000 & 3.5 ande & $7 \mathrm{~m}$ & sepedanoror & kelas $1 \mathrm{~A}$ & retiongnising \\
\hline Wharana oviti & lenglep & Res500.00 & 1.2 and & $7 \mathrm{~mm}$ & sepeded notor & kelas 18 & rettrongingin \\
\hline With & lenglep & Re. 1000.000 & $159010 \mathrm{k}$ & $5 \mathrm{~km}$ & sepeded notor & kelas $1 \mathrm{C}$ & retangrisich \\
\hline M. bafif & lenglop & Ro. 2000000 & 3.5 ande & $7 \mathrm{~km}$ & sepeded notor & keles $2 \mathrm{~A}$ & retarlangisich \\
\hline Rajugstian & lenglep & Rp. 1000.000 & 1.2 ank & $5 \mathrm{~m}$ & Sepeded notor & kelas $1 \mathrm{C}$ & retangninich \\
\hline Yoni ahrar & lenglep & Ro5000000 & $3.59010 k$ & $5 \mathrm{~km}$ & sepeda motor & kelas $4 \mathrm{~A}$ & rettanginisin \\
\hline
\end{tabular}

Matrik Hasil adalah hasil dari kumpulan nilai prioritas pada kriteria dan sub kriteria yang akan di pakai sebagai panduan penilaian pada bantuan siswa miskin.

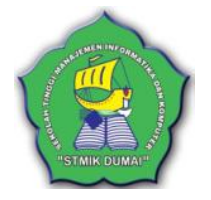

Tabel 6. Penilaian siswa bantuan siswa miskin

\begin{tabular}{|c|c|c|c|c|c|c|c|c|c|}
\hline lemansilia & 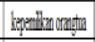 & 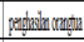 & 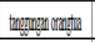 & $\mathrm{ghtmm}$ & distrasyratial & bex & pratugatin & jimth & rath \\
\hline Dinsogryng & 0.2 & 02 & 0.9 & 0117 & Q4. & 0.4 & 0.5 & 209 & 2 \\
\hline Dinstrangwar & 0.07 & 0.5 & OLI & QH & 0.13 & 0.13 & 0.5 & 191 & 6 \\
\hline Fath alengeh & 059 & 0.5 & O.4. & 039 & Q.6 & 0.13 & 0.15 & 271 & 1 \\
\hline farsisulindrovg & 0.07 & 0.5 & 0.17 & 039 & 0.13 & 0.31 & 0.15 & 1.77 & 9 \\
\hline Giagloin & 0.07 & 0.2 & 0.9 & DH & 0.13 & 0.31 & 0.5 & 199 & 5 \\
\hline hasconos ati & 0.07 & 0.5 & 0.17 & DH & 0.13 & 0.31 & 0.5 & 18. & 7 \\
\hline With & 007 & 02 & OLI & 039 & 0.13 & 0.11 & 0.15 & 199 & 4 \\
\hline W. 2 . aff & 0.07 & 0.35 & 0.9 & DH & 0.13 & 0.4 & 0.15 & 207 & 3 \\
\hline Rijgsion & 007 & 0.2 & 0.17 & 039 & 0.13 & 031 & 0.15 & 172 & 10 \\
\hline Voinzaras & 0.07 & 0.5 & 039 & 039 & 0.13 & 0.13 & 0.5 & 181 & 8 \\
\hline
\end{tabular}

Dari perhitungan tersebut total nilai setiap siswa akan digunakan sebagai acuan untuk penilaian siapa siswa yang layak yang dapat direkomendasikan untuk mendapatkan bantuan siswa miskin. Seperti terlihat pada tabel. 6 .

Tabel. 7 .Perhitungan nilai hasil akhir

Pada tabel diatas menampilkan nilai yang diinputkan sebelumnya dan menghasilkan peranking siswa yang mendapatkan bantuan tersebut.

Dan yang mendapatkan pe rankingan yang tertinggi pertama siswa bernama fahril alamsyah dengan total 2,71 dan yang perangkingan terakhir adalah siswa bernama Raju gustian 1.72.

b. Implementasi Sistem

1. Tampilan Form Input Siswa

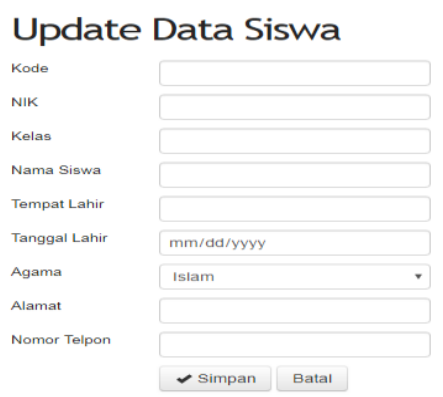

Gambar 3. Form Input Siswa 
IN F ORMA T I K A

Jurnal Informatika, Manajemen dan Komputer, Vol.11 No.2, Desember 2019

eISSN : 2580-3042

pISSN : 1979-0694

Form ini digunakan untuk menginput data siswa yang mendapatkan bantuan siswa miskin.

2. Tampilan Form Input Kriteria

\section{Update Data Kriteria}

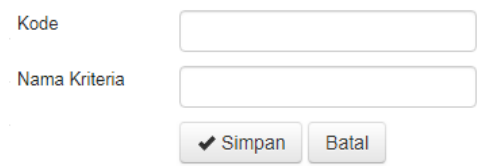

Gambar 4. Form Input Criteria

Form data kriteria untuk menginputkan data kriteria apa daja yang akan menjadi penilaian seeleksi pada siswa dengan perhitungan analytical hierarcy proses.

3. Tampilan form input data sub kriteria

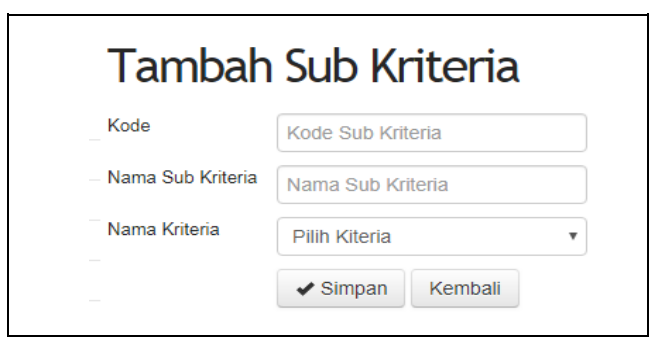

Gambar 5. Form input sub criteria

Form data sub kriteria untuk menginputkan data sub kriteria apa daja yang akan menjadi penilaian seeleksi pada siswa dengan perhitungan analytical hierarcy proses

4. Tampilan nilai perbandingan criteria

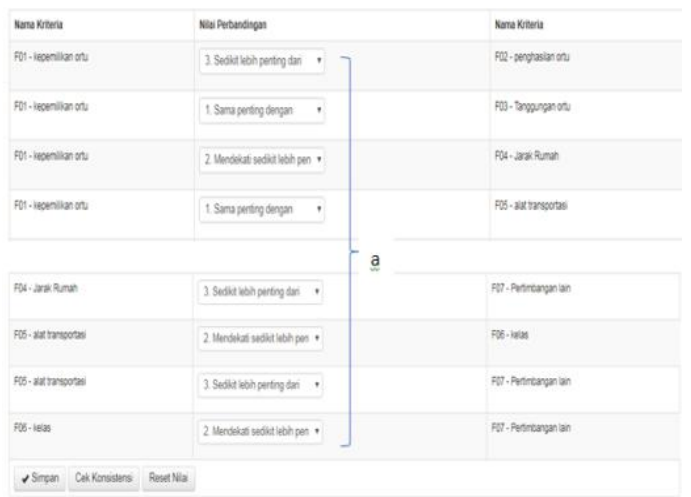

Gambar 6. Tampilan nilai perbandingan criteria

Form nilai perbandingan kriteria ini adalah tampilan data kriteria yang sudah di inputkan dan yang akan menjadi panduan untuk penilaian pada perhitungan analytical hierarcy proses.

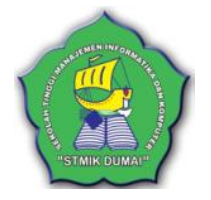

5. Tampilan Hasil perbandingan Kriteria

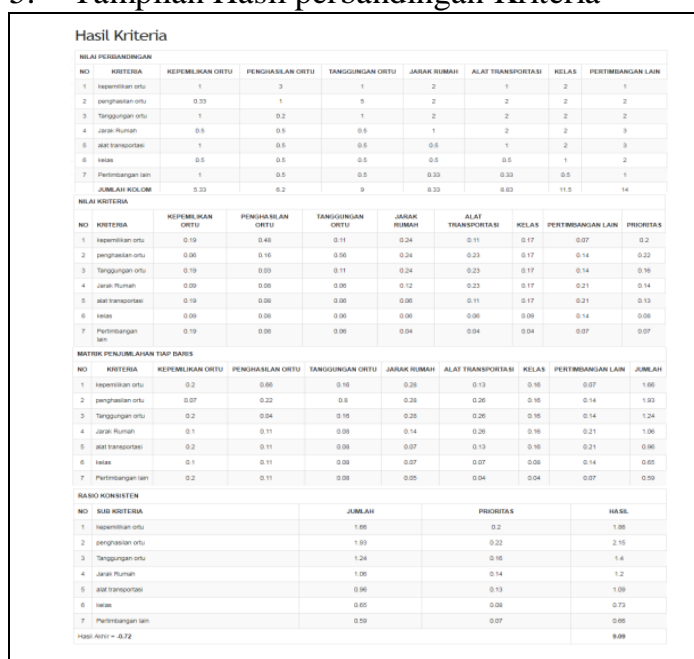

Gambar 7. Tampilan hasil perbandingan kriteria

Form hasil perbandingan kriteria adalah hasil dari perhitungan perbandingan kriteria yang menghasilkan nilai prioritas kriteria.

6. Tampilan Matrik Hasil

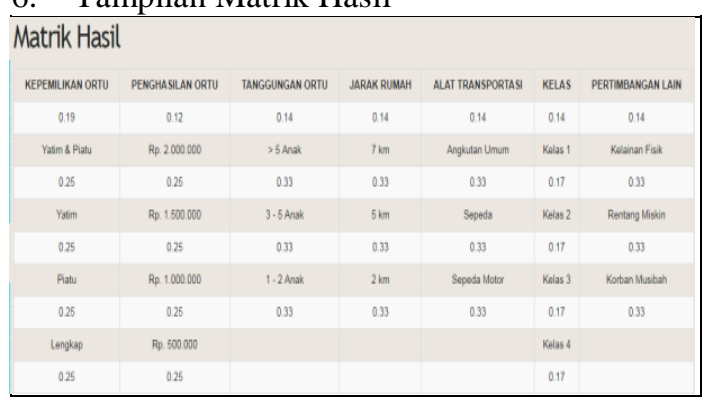

Gambar 8. Tampilan matrik hasil

Tampilan matrik hasil adalah tampilan untuk menampilkan nilai prioritas kriteria dan sub kriteria.dan nilai pada matrik hasil akan menjadi nilai keterntuan pada penilaian siswa .

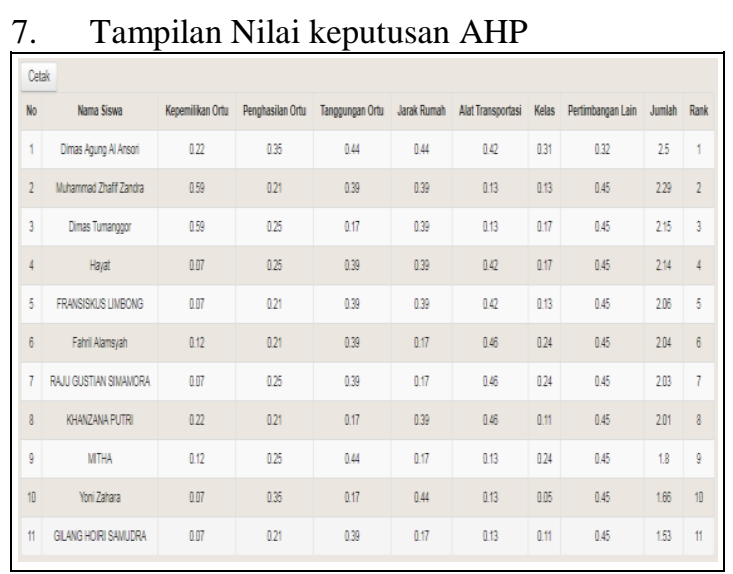

Gambar 9. Tampilan nilai keputusan AHP 
IN F ORM T I K

Jurnal Informatika, Manajemen dan Komputer, Vol.11 No.2, Desember 2019

eISSN : 2580-3042

pISSN : 1979-0694

Tampilan Nilai Keputusan Analitycal Hierarcy Process (AHP). Halaman ini berfungsi untuk menampilkan hasil dari penilaian penerima bantuan dan menampilkan jumlah dan hasil rank sesuai urutan dari nilai tertingga dan nilai terendah pada penilaian siswa. Nilai keputusan AHP ini di hasilkan dari tabel nilai matrik hasil yang menjadikan patokan nilai untuk penilaian siswa . Klik tombol cetak jika ingin mencetak nilai keputusan ahp yang akan menjadi laporan penilaian rank siswa.

\section{KESIMPULAN}

Dari hasil analisis dan penelitian yang telah dilakukan, maka dapat diambil kesimpulan sebagai berikut :

1. Hasil dari penelitian ini adalah peringkat nilai prioritas kriteria penghasilan orangtua mendapatkan nilai tertinggi dari nilai prioritas kriteria yang lainya. Hal ini dibuktikan dengan nilai bobot prioritas kriteria penghasilan orangtua dengan nilai 0.25 atau sebanding dengan $25 \%$ dari total kriteria yang ada .

2. Hal ini dibuktikan dengan nilai bobot prioritas sub kriteria yatim \& piatu dengan nilai 0.59 atau sebanding dengan $59 \%$ dari total sub kriteria yang ada, hasil ini dituangkan dalam tabel matrik hasil

3. Dari hasil nilai keputusan Analytical Hierarchy Process menghasilkan perankingan siswa yang mendapatkan rekomendasi penerima bantuan siswa miskin. Hal ini dibuktikan dengan siswa yang mendapatkan nilai rank tertinggi pertama yaitu siswa Fahril Alamsyah dengan jumlah nilai 2,71 dari jumlah yang ada, selanjutnya ranking kedua yaitu siswa Dimas Agung dengan jumlah nilai 2,1, siswa ke tiga Muhammad Zhaff Zandra dengan nilai 2,07, siswa ke empat Gilang Hoiri samudara dengan jumlah nilai 2 dan siswa kelima Mitha dengan jumlah nilai 2.

4. Dari 10 siswa yang di rekomendasi hanya 5 siswa yang mendaptkan bobot nilai tertinggi.

\section{REFERENSI}

Arief, M. H., Thamrin, I. I., \& Budiawan, R. (2015). Sistem Pengolahan Data Dan Seleksi Penerima Bantuan Beasiswa Siswa Miskin ( Bsm ) Berbasis Web Dan Android , ( Studi Kasus: Madrasah Ibtidaiyah Miftahul Ulum , Jember ). 1(1), 305-312.

Ayu Riana Devi Aprilia, I. W. (2018). Analytic Hierarchy Process Dan Visualisasi Pemetaan Di Wilayah Kabupaten Jepara. 9(1), 479-490.

Bain Khusnul Khotimah, Firli Irhamni, Moh. Zein Saedi, A. D. C. (2015). Sistem Informasi Pengukuran Kinerja Ukm. Jurnal Ekonomi Dan Bisnis, 978-979.

Hardianti, M., Hidayatullah, R., Pratiwi, F., \& Hadiansa, A. (2018). Perancangan Sistem Pendukung Keputusan Penentuan Penerima Bantuan Daerah Berdasarkan Tarif Hidup Masyarakat Menggunakan Metode Saw. Jurnal Vokasional Teknik Elektronika Dan Informatika, 6(2).

Kadir, A. (2014). Pengenalan Sistem Informasi (Andi). Yogyakarta.

Kusrini. (2007). Konsep Dan Aplikasi Sistem Pendukung Keputusan (Andi, Ed.). Yogyakarta.

Pratama, D., \& Hansun, S. (2017). Aplikasi Rekomendasi Tempat Makan Menggunakan Algoritma Slope One Pada Platform Android. Ijccs (Indonesian Journal Of Computing And Cybernetics Systems), 11(1), 11. Https://Doi.Org/10.22146/Ijccs. 15558

Rahmiati, \& Yenni, H. (2019). Pada Koperasi Dengan Metode Ahp. 11(1), 30-36.

Sutabri, T. (2012). Konsep Sistem Informasi (Andi, Ed.). Yogyakarta.

Turban, E. (2005). Dicision Support Systems And Intelligent Systems (Andi, Ed.). Yogyakarta. 